\title{
Synthesis, in silico Study and Antimicrobial Evaluation of New Selenoglycolicamides
}

\author{
Helivaldo D. S. Souza, ${ }^{a}$ Roxana P. F. de Sousa, ${ }^{a}$ Bruno F. Lira, ${ }^{a}$ Raquel F. Vilela, ${ }^{a}$ \\ Nathalie H. P. B. Borges, ${ }^{b}$ José P. de Siqueira-Junior, ${ }^{b}$ Edeltrudes O. Lima, ${ }^{c}$ \\ Jeane U. G. Jardim, ${ }^{c}$ Gracielle A. T. da Silva, ${ }^{c}$ José M. Barbosa-Filho ${ }^{c}$ and \\ Petrônio F. de Athayde-Filho ${ }^{(i), a}$ \\ ${ }^{a}$ Departamento de Química, Universidade Federal da Paraíba, 58051-900 João Pessoa-PB, Brazil \\ ${ }^{b}$ Departamento de Biologia Molecular, Universidade Federal da Paraíba, \\ 58051-970 João Pessoa-PB, Brazil \\ 'Departamento de Ciências Farmacêuticas, Universidade Federal da Paraíba, \\ 58051-900 João Pessoa-PB, Brazil
}

\begin{abstract}
Nine new compounds derived from selenoglycolic acid were synthesized, and their structures were fully characterized by elemental analysis, infrared (IR), ${ }^{1} \mathrm{H}$ and ${ }^{13} \mathrm{C}$ nuclear magnetic resonance (NMR). The compounds were evaluated in an in silico study and showed strong to moderate antibacterial activity against several strains of Staphylococcus aureus. In particular, three compounds exhibited excellent antibacterial activity, with minimum inhibitory concentrations (MICs) between 16 and $64 \mu \mathrm{g} \mathrm{mL}{ }^{-1}$. Furthermore, two of the nine compounds showed antifungal activity, with MIC of 1024 and $512 \mu \mathrm{g} \mathrm{mL}^{-1}$. In silico studies of the parameters of Lipinski's rule of five indicate that these compounds have potential to be new drug candidates.
\end{abstract}

Keywords: selenoglycolic acid, selenoglycolicamides, antibacterial activity, antifungal activity

\section{Introduction}

The treatment of bacteria and fungi has become a growing problem that concerns clinicians, the pharmaceutical industry and chemists, due to increased resistance to the available medicines in the market. These micro-organisms, when they become multidrug resistant, are one of the major causes of the increased mortality of the global population. ${ }^{1}$

Antibiotics shut down or subvert essential bacterial functions. The resistance mechanisms appear to exploit every possible strategy of preventing a drug from hitting its target. The major types of clinically relevant resistance mechanisms have been studied for a long time. The efflux phenomenon, found in many species of bacteria, fungi and mammalian cells, is shown to occur through default accumulation within cells and is responsible for exporting drugs from cells over the action of proteins, resulting in low intracellular drug concentrations. ${ }^{2}$

Many of these proteins are associated with treatment failure in nosocomial- and community-acquired infections by Staphylococcus aureus. ${ }^{3}$ For example, TetK and MsrA

*e-mail: athayde-filho@quimica.ufpb.br are specific transporters that export tetracyclines and macrolides, respectively, and NorA is the most studied and was the first described multidrug and toxin extrusion protein in $S$. aureus, ${ }^{4,5}$ which confers resistance to a wide range of compounds, including fluoroquinolones, ethidium bromide, acriflavine, ammonium compounds, chlorhexidine, dequalinium and others. ${ }^{6}$

The active efflux of drugs confers a moderate level of resistance, causing an increase of up to 64 times the minimum inhibitory concentration (MIC) at the expense of increased expression of efflux pumps ${ }^{7}$ or through synergism with other forms of resistance. ${ }^{8,9}$ Due to this, it has shown promise for improving the effectiveness of antimicrobial agents and its combination with efflux pump inhibitors (EPIs), which, besides expanding the usefulness of existing antibiotics, reduces the emergence of resistant mutant strains. ${ }^{10,11}$

One group of compounds that has been highlighted in the scientific community, both in the synthesis and the development of new therapeutic agents, is composed of organoselenium compounds. These compounds are obtained from reactions with elemental selenium ${ }^{12}$ and electrophilic ${ }^{13,14}$ or nucleophilic ${ }^{15}$ reagents (inorganics 
or organics) containing selenium. The organoselenium compounds reported in the literature are presented as biologically active molecules with antibacterial, ${ }^{15-17}$ antifungal, ${ }^{18-21}$ anti-inflammatory, ${ }^{22}$ antinociceptive, ${ }^{22}$ antiparasitic ${ }^{23-25}$ and antiviral activities. ${ }^{26,27}$

Considering the potential of organoselenium compounds in the synthesis of new pharmaceutical drug candidates, a series of nine selenoglycolicamides were planned for evaluating an in silico study as new structures of drug candidates, obeying the Lipinski's rules. The compounds were synthesized using our selenoglycolic acid synthesis protocol, and these are the early studies of microbiological activity against bacteria (Staphylococcus aureus) and fungi (Candida albicans and Candida tropicalis).

\section{Results and Discussion}

\section{Chemistry}

The synthesis of the compounds derived from selenoglycolic acid used our previously described procedures ${ }^{28}$ with few modifications. The selenoglycolicamides (7a-i) were obtained in four synthetic steps, as described in Scheme 1.

The first stage produces $\alpha$-chloro- $N$-arylacetamides (2a-i) by $N$-acetylation reaction with arylamines $(\mathbf{1 a - i )}$ and 2-chloroacetyl chloride, in triethylamine and $\mathrm{CH}_{2} \mathrm{Cl}_{2}$ as solvent. ${ }^{29}$ The second to fourth stages are a one-pot synthesis. The second stage produces sodium hydrogen selenide (4) by the powdered gray selenium (3) reaction with sodium borohydride in aqueous solution. In the third stage, NaHSe react with aroyl chlorides, forming sodium aroylselenides (6). The fourth stage produces selenoglycolicamides (7a-i) with a yield of 70-80\% by an aroylselenide (6) reaction with $\alpha$-chloro- $N$-arylacetamides (2a-i). The purity of the compounds was checked by examining the melting ranges.

The selenoglycolicamide structures were confirmed using infrared (IR), ${ }^{1} \mathrm{H}$ and ${ }^{13} \mathrm{C}$ nuclear magnetic resonance (NMR) spectroscopic techniques. The principal characteristic of the IR spectra is the $\mathrm{C}=\mathrm{O}$ stretch. All of the compounds (7a-i) presented two $\mathrm{C}=\mathrm{O}$ functional group absorptions at $1651-1670 \mathrm{~cm}^{-1}$, corresponding to $(-\mathrm{NH})-\mathrm{C}=\mathrm{O}$, and at $1670-1674 \mathrm{~cm}^{-1}$, corresponding to $(-\mathrm{Se})-\mathrm{C}=\mathrm{O}$. For all compounds, the $\mathrm{N}-\mathrm{H}$ stretch of the amide groups was approximately $3270 \mathrm{~cm}^{-1}$. Specifically, for compounds $\mathbf{7 b}$ and $\mathbf{7} \mathbf{i}$, the nitro group was characterized by two absorption bands in the ranges of $1529-1510 \mathrm{~cm}^{-1}$ and $1362-1342 \mathrm{~cm}^{-1}$, respectively. In the ${ }^{1} \mathrm{H}$ NMR spectra for all compounds (7a-i), two $\alpha$-hydrogen atoms (methylene group) had chemical shifts $(\delta)$ as singlets in the range of $\delta 3.77-4.01 \mathrm{ppm}$. The hydrogen atoms of the amide group had chemical shifts as singlets in the range of $\delta$ 8.24-10.91 ppm. The hydrogen atoms of the attached benzene ring had $\delta$ between 6.5 and $8.40 \mathrm{ppm}$. In the 7c spectra, the ethyl group was characterized by a triplet at $\delta 1.19 \mathrm{ppm}$ representing the three hydrogen atoms and by a quartet at $\delta 2.59 \mathrm{ppm}$ for two secondary hydrogen. In the 7d spectra, the methyl group was characterized by a singlet at $\delta 2.29 \mathrm{ppm}$ for three primary hydrogens. Specifically, for the $\mathbf{7 g}$ compound, the isopropyl group was characterized by a doublet at $\delta 1.21 \mathrm{ppm}$ representing the six hydrogen atoms and by a septet at $\delta 2.68 \mathrm{ppm}$ for the tertiary hydrogen. In the $\mathbf{7 h}$ spectra, the methoxy group was characterized by a singlet at $\delta 3.77 \mathrm{ppm}$. For the ${ }^{13} \mathrm{C}$ NMR spectra, the carbon from the $\mathrm{C}=\mathrm{O}$ corresponding to the

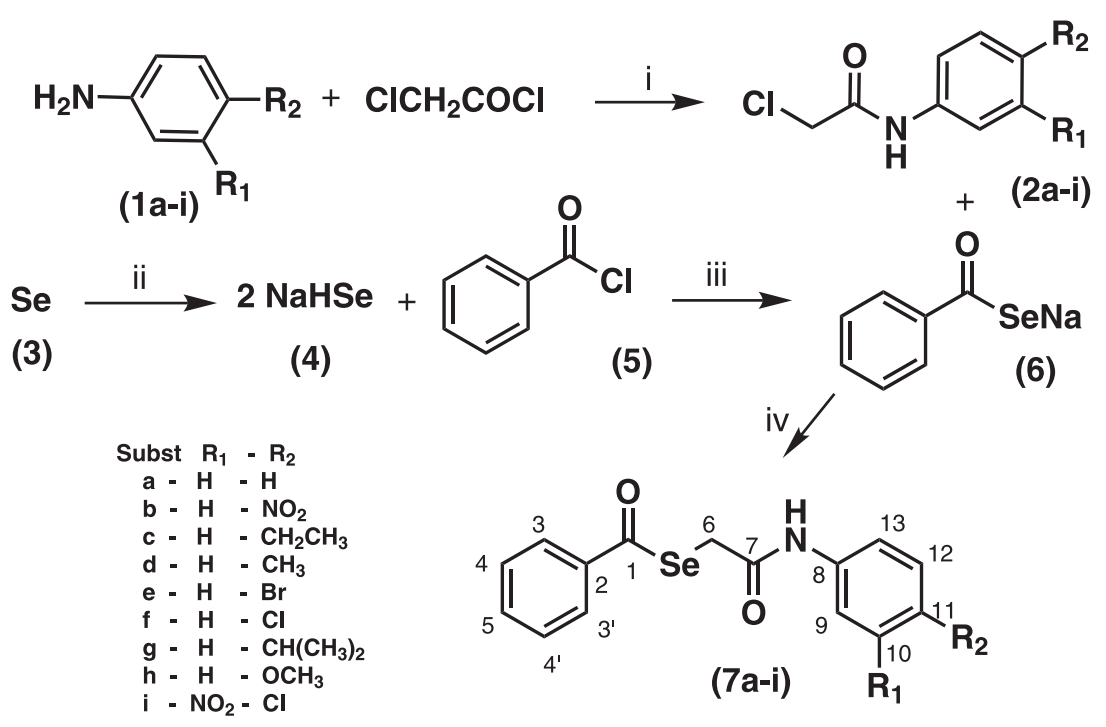

Scheme 1. Synthetic route for the synthesis of the target molecules. Reagents and conditions: (i) $\mathrm{Et}_{3} \mathrm{~N}, \mathrm{CH}_{2} \mathrm{Cl}_{2}, 0$-rt (room temperature), 20 h, 95-85\%; (ii) $\mathrm{NaBH}_{4}, \mathrm{H}_{2} \mathrm{O}$, rt; (iii) $\mathrm{H}_{2} \mathrm{O}$, rt, $1 \mathrm{~h}$; (iv) $\mathrm{H}_{2} \mathrm{O}, \mathrm{rt}, 70-80 \%$. 
selenol ester group was characterized by $\delta$ between 193.0 and $197.6 \mathrm{ppm}$, and the $\mathrm{C}=\mathrm{O}$ corresponding to the amide group was characterized by $\delta$ between 167 and $168 \mathrm{ppm}$. The $\alpha$-carbon was characterized by $\delta$ between 28.0 and $29.0 \mathrm{ppm}$, and all $\delta$ attributed to aromatic carbons were characterized by peaks between 117.0 and $156.5 \mathrm{ppm}$. In the spectra of the compound $\mathbf{7 c}$, two additional signals in the aliphatic region at $\delta 28.3$ and $15.7 \mathrm{ppm}$, attributed to carbons of the ethyl group, were observed. In the spectra of the compound $\mathbf{7 d}$, an additional signal in the aliphatic region at $\delta 21.0 \mathrm{ppm}$ for the carbon of the methyl group was observed. In the $\mathbf{7 g}$ spectra, two additional signals at $\delta 33.7$ and $24.1 \mathrm{ppm}$, attributed to the carbons of the isopropyl group, were observed. In the $\mathbf{7 h}$ spectra, an additional signal at $\delta 55.6 \mathrm{ppm}$ attributed to the carbon of the methoxy group was observed.

\section{In silico study}

The process of new drug development requires a great deal of time and resources. The theoretical studies have a fundamental role to minimize these factors because they show indications of potential drug applications. Several authors mention that it is not enough for a compound to present high biological activity and low toxicity to be tested as a drug; it is also necessary to meet the ADME pharmacokinetics parameters (absorption, distribution, metabolism and excretion), which determine the access and the concentration of the compound in the therapeutic target and its subsequent elimination by the organism..$^{30,31}$ Many drug candidates can be discarded for presenting unfavorable pharmacokinetics. The ADME parameters can be verified by in silico studies based on calculated physico-chemical standards. These standards emphasize lipophilicity, water solubility, molecule size and flexibility.
Prior analysis of these parameters drastically reduces the necessary time for the pharmacokinetic study in the clinical phase. Many studies relating physico-chemical standards with ADME parameters were performed in the 90s. The most widespread study was from the pioneer Lipinski et al., ${ }^{32}$ which presented a relationship between pharmacokinetics and physico-chemical parameters, indicating that a molecule will have high potential as drug if it highly resembles existing drugs, a phenomenon known as drug-likeness; the study established standards named "Rules of 5" by Lipinski, which consider only four factors (whose values are multiples of five): molar mass $\leq 500 \mathrm{~g} \mathrm{~mol}^{-1}, \log \mathrm{P} \leq 5$, number of hydrogen bond acceptors $\leq 10$ (accounted in function of $\mathrm{N}$ or $\mathrm{O}$ atoms in the molecule), and number of hydrogen bond donors $\leq 5$ (accounted in function of $\mathrm{NH}$ or $\mathrm{OH}$ groups in the molecule).

In this work, an in silico study of selenoglycolicamides 7a-i was performed to verify the Lipinski parameters using OSIRIS Property Explorer, ${ }^{33}$ Molinspiration ${ }^{34}$ and Swiss $\mathrm{ADME}^{35}$ software. The topological polar surface area (TPSA), absorption percentage (\%ABS), drug-likeness and drug score were included in this study. The absorption percentage was calculated according to Zhao et al., ${ }^{36}$ and is expressed by the equation \%ABS $=109-(0.345 \times$ TPSA $)$. The calculated values for the studies are shown in Table 1.

According to the results obtained from the in silico approach, all of the compounds obeyed the Rules of 5 by Lipinski, thus indicating a good oral bioavailability during drug administration. The obtained TPSA values for all compounds were below $140 \AA^{2}$, indicating a great permeability of the compound in the cellular plasma membrane. The absorption percentage showed a great absorption of the compounds, as the lowest absorptions for the compounds $\mathbf{7 b}$ and $\mathbf{7 i}$ were $77.26 \%$, and the best

Table 1. In silico study of the selenoglycolicamide compounds

\begin{tabular}{|c|c|c|c|c|c|c|c|c|c|c|c|}
\hline \multirow{2}{*}{ Compound } & \multicolumn{5}{|c|}{ Lipinski parameter } & \multirow{2}{*}{ TPSA / $\AA^{2}$} & \multirow{2}{*}{$\% \mathrm{ABS} / \%$} & \multirow{2}{*}{$\log S$} & \multirow{2}{*}{ Class } & \multirow{2}{*}{$\begin{array}{c}\text { Drug } \\
\text { likeness }\end{array}$} & \multirow{2}{*}{$\begin{array}{l}\text { Drug } \\
\text { score }\end{array}$} \\
\hline & MW & HBD & HBA & milog $\mathrm{P}$ & $\mathrm{nV}$ & & & & & & \\
\hline $7 a$ & 318.23 & 1 & 3 & 3.23 & 0 & 46.17 & 93.07 & -3.53 & soluble & -4.23 & 0.25 \\
\hline $7 b$ & 363.23 & 1 & 6 & 3.19 & 0 & 91.99 & 77.26 & -3.57 & soluble & -17.9 & 0.23 \\
\hline $7 c$ & 346.28 & 1 & 3 & 4.14 & 0 & 46.17 & 93.07 & -4.16 & moderately & -2.69 & 0.19 \\
\hline $7 d$ & 332.26 & 1 & 3 & 3.68 & 0 & 46.17 & 93.07 & -3.82 & soluble & -3.88 & 0.24 \\
\hline $7 e$ & 397.13 & 1 & 3 & 4.04 & 0 & 46.17 & 93.07 & -4.43 & moderately & -4.48 & 0.20 \\
\hline $7 f$ & 352.67 & 1 & 3 & 3.91 & 0 & 46.17 & 93.07 & -4.12 & moderately & -1.39 & 0.26 \\
\hline $7 \mathrm{~g}$ & 360.31 & 1 & 3 & 4.74 & 0 & 46.17 & 93.07 & -4.37 & moderately & -4.84 & 0.20 \\
\hline $7 \mathrm{~h}$ & 348.26 & 1 & 4 & 3.29 & 0 & 55.40 & 89.88 & -3.59 & soluble & -3.6 & 0.25 \\
\hline $7 \mathbf{i}$ & 397.67 & 1 & 6 & 3.80 & 0 & 91.99 & 77.26 & -4.16 & moderately & -11.56 & 0.19 \\
\hline
\end{tabular}

Physicochemical properties: MW: molecular weight; HBD: hydrogen bonding donor; HBA: hydrogen bonding acceptor; milog P: octanol/water partition coefficient based on Molinspiration milog P model; $n$ V: number of violations; TPSA: total polar surface area; \%ABS: adsorption percentage; log S: coefficient of solubility determined by the ESOL method calculated on SwissADME; Class: insoluble $<-10<$ poor $<-6<$ moderately $<-4<$ soluble $<-2<$ very $<$ $0<$ highly. 
absorption for the compounds $\mathbf{7 a}, \mathbf{7 c}, \mathbf{7 d}, \mathbf{7 e}, \mathbf{7 f}$ and $\mathbf{7 g}$ was 93.08\%, as shown in Table 1.

The $\log \mathrm{S}$ (coefficient of solubility determined by the ESOL method calculated on SwissADME) of many commercial drugs shows a value greater than -4.00 . As shown in Table 1, the log $\mathrm{S}$ presented values in the range of -4.43 to -3.53 for compounds $7 \mathbf{a}-\mathbf{i}$. From these results, $\mathbf{7 a}, \mathbf{7 b}, \mathbf{7 d}$ and $\mathbf{7 h}$ compounds are considered soluble, while $7 \mathrm{c}, 7 \mathrm{e}, \mathbf{7 f}, \mathbf{7 g}$ and $\mathbf{7 i}$ are considered moderately soluble.

The drug-likeness evaluates the comparison of the investigated compounds through fragments and/or physical properties similar to those of the most known drugs, and they must present positive values. The obtained values in this study are in the range of -17.9 and -1.39 . The drug score value combines the records of drug-likeness, lipophilicity, solubility, molecular mass and toxicity risks into a single numerical value, which varies from 0.0 to 1.0 and can be used to predict the global potential of one compound as a new drug candidate. The obtained values from this approach were between 0.12 and 0.26 , suggesting that these compounds have potential to become new drug candidates.

\section{Biological study}

\section{Antibacterial activity}

The selenoglycolicamides 7a, $7 \mathbf{f}$ and $7 \mathbf{i}$ showed relevant antibacterial activity (MIC $\leq 64 \mu \mathrm{g} \mathrm{mL}^{-1}$ ) against the strains Staphylococcus aureus IS-58, RN-4220 and SA-1199B, which over-express the effluent pumps TetK, MsrA and NorA, respectively. The other selenoglycolicamide compounds showed MIC values between 128-256 $\mu \mathrm{g} \mathrm{mL}^{-1}$, considered low inhibitory activity (Table 2).

According to Gibbons, ${ }^{37}$ compounds (from natural products) with MIC above $100 \mu \mathrm{gL}^{-1}$ are considered poorly active antimicrobial agents, while those with MIC below $10 \mu \mathrm{g} \mathrm{mL}^{-1}$ (ideal $\leq 2 \mu \mathrm{g} \mathrm{mL}{ }^{-1}$ ) are considered of great interest to pharmaceutical industries. However, according to Radhakrishna et al., ${ }^{38}$ ester derivatives from selenoglycolic acids and their analogues, are considered moderate to good active agents against Staphylococcus aureus bacteria with MIC values between 0.1-50 $\mathrm{mg} \mathrm{mL}^{-1}$ and the organoselenium compounds from ebselen derivatives are considered highly active against Staphylococcus aureus with MIC values between $2.0-32 \mu \mathrm{g} \mathrm{mL}^{-1} .{ }^{39}$

In general, for the efflux strains tested, of the nine compounds $\mathbf{7 a - i}$, only three compounds (7a, $7 \mathbf{f}$ and $\mathbf{7 i}$ ) were more effective, presenting MIC values $\leq 64 \mu \mathrm{g} \mathrm{mL}^{-1}$, while the other selenoglycolicamides presented MIC values between $256-128 \mu \mathrm{g} \mathrm{mL}^{-1}$, considered low inhibitory activity. The 7a compound presented activity against the strains IS-58 and RN-4220 with an MIC of $32 \mu \mathrm{g} \mathrm{mL}^{-1}$ and in the strain SA-1199B with an MIC of $128 \mu \mathrm{g} \mathrm{mL}^{-1}$. The 7f compound presented activity against the strain IS-58, with an MIC of $16 \mu \mathrm{g} \mathrm{mL}-1$, and the strains RN-4220 and SA-1199B, with an MIC of $32 \mu \mathrm{g} \mathrm{mL}-1$. The $7 \mathbf{i}$ compound presented an MIC of $32 \mu \mathrm{g} \mathrm{mL}-1$ for the strain IS-58, $64 \mu \mathrm{g} \mathrm{mL}{ }^{-1}$ for the strain $\mathrm{RN}-4220$ and $16 \mu \mathrm{g} \mathrm{mL} \mathrm{m}^{-1}$ for the strain SA-1199B. Thus, the compounds $7 \mathbf{a}, \mathbf{7 f}$ and $7 \mathbf{i}$ were shown to be better than the standard compound used in the experiment, chloramphenicol. On the other hand, the compounds $\mathbf{7 b}$ and $\mathbf{7 h}$ presented identical activities against the strains IS-58 and RN-4220, with an MIC of $128 \mu \mathrm{g} \mathrm{mL} \mathrm{m}^{-1}$. The compounds $\mathbf{7 c}, \mathbf{7} \mathbf{d}$ and $\mathbf{7 e}$ presented an MIC of $256 \mu \mathrm{g} \mathrm{mL} \mathrm{m}^{-1}$ against three efflux species (IS-58, RN-4220 and SA-1199B). In the ATCC 25923 strain, the compounds showed low activity, with the exception of compound 7a, which presented activity results identical to chloramphenicol.

According to Zloh and co-workers, ${ }^{40,41}$ a characteristic of substances that possess a high degree of lipophilicity is

Table 2. Minimum inhibitory concentrations (MIC) of selenoglycolicamides against strains of S. aureus

\begin{tabular}{|c|c|c|c|c|}
\hline \multirow{3}{*}{ Selenoglycolicamide } & \multicolumn{4}{|c|}{ Minimum inhibitory concentration / $\left(\mu \mathrm{g} \mathrm{mL} \mathrm{mL}^{-1}\right)$} \\
\hline & \multicolumn{4}{|c|}{ Strains (efflux pump) } \\
\hline & ATCC 25923 & IS-58 (TetK) & RN-4220 (MsrA) & SA-1199B (NorA) \\
\hline $7 \mathbf{a}$ & 128 & 32 & 32 & 128 \\
\hline $7 \mathbf{b}$ & 256 & 128 & 128 & 256 \\
\hline 7c & $>256$ & 256 & 256 & 256 \\
\hline 7d & $>256$ & 256 & 256 & 256 \\
\hline $7 e$ & $>256$ & 256 & 256 & 256 \\
\hline $7 \mathbf{f}$ & $>256$ & 16 & 32 & 32 \\
\hline $7 \mathrm{~g}$ & $>256$ & 128 & 256 & 256 \\
\hline $7 \mathbf{h}$ & 256 & 128 & 128 & 256 \\
\hline $7 \mathbf{i}$ & $>256$ & 32 & 64 & 16 \\
\hline Cloramphenicol & 128 & 64 & 64 & 64 \\
\hline
\end{tabular}

TetK: tetracycline efflux protein; MsrA: macrolides efflux protein; NorA: fluoroquinolone efflux protein. 
the ability to inhibit the multidrug-resistant bacteria (MRB) that have efflux proteins as a defense mechanism. This study showed that the obtained results were not consistent with the Zloh and co-workers ${ }^{40,41}$ affirmation, i.e., this rule does not apply to glycolic amides. The compounds $7 \mathbf{g}, 7 \mathbf{c}$ and 7e showed the highest lipophilicity values, and they should demonstrate antimicrobial action results consistent with the Zloh co-workers ${ }^{40,41}$ affirmation; however, they were not the most active strains tested. The compounds with halogens in their structure can increase lipophilicity, as was shown by the compounds $\mathbf{7 f}$ and $\mathbf{7 i}$, both with chlorine, which presented better results against the strains IS-58 (TetK), RN-4220 (MsrA) and SA-1199B (NorA). However, compound 7e, with bromine, did not show significant antibacterial activity. Although compound $\mathbf{7 b}$ possessed a nitro group, which is a pharmacophoric group capable of promoting an increase in the hydrophobic character of the molecule, ${ }^{42,43}$ it did not show antibacterial activity. However, the 7i compound, which contains a chlorine atom and a nitro group, demonstrated a relevant antibacterial effect. For the compounds $\mathbf{7 c}, \mathbf{7 d}, \mathbf{7 g}$ and $\mathbf{7 h}$ that possess activating groups on the benzene ring, effective antimicrobial action against the tested strains was not observed.

\section{Antifungal activity}

The in vitro antifungal activity of compounds $\mathbf{7 a - i}$ was evaluated by the microdilution method with four strains of pathogenic fungi, Candida albicans (ATCC-76485 and LM-5) and Candida tropicalis (ATCC-13803 and LM-96), using nystatin as the standard drug. The compounds were tested at concentrations of 64 to $1024 \mu \mathrm{g} \mathrm{mL}-1$ and solubilized in dimethyl sulfoxide (DMSO, Merck), in a proportion up to $10 \%$ to avoid interference with the microorganisms. The antimicrobial activity of the products was interpreted and considered as active or inactive based on the following criteria: $50-500 \mu \mathrm{gL}^{-1}=$ strong/great activity; $600-1500 \mu \mathrm{g} \mathrm{mL}^{-1}=$ moderate activity; and above $1500 \mu \mathrm{g} \mathrm{mL}^{-1}=$ weak activity or inactive product.

Of the nine compounds tested, compounds $\mathbf{7 b}-\mathbf{7 g}$ did not exhibit inhibitory activity against the strains mentioned in the evaluation. The 7 a compound demonstrated an inhibition of $100 \%$ and a moderate activity against the four strains of Candida (C. albicans ATCC-76485, C. albicans LM-5, C. tropicalis ATCC-13803 and C. tropicalis LM-96), at an MIC of $1024 \mu \mathrm{g} \mathrm{mL}^{-1}$. However, the $7 \mathbf{i}$ compound presented an inhibition of $50 \%$ with a great activity against two of the four strains of Candida (C. tropicalis ATCC-13803 and C. tropicalis LM-96), with an MIC of $512 \mu \mathrm{g} \mathrm{mL}-1$. The results (Table 3), therefore, were considered between good and moderate in terms of biological activity and taking into consideration the established parameters. ${ }^{44}$

\section{Conclusions}

In this short report, we performed an in silico study of selenoglycolicamides $\mathbf{7 a - i}$, all of which obeyed the Rules of 5 by Lipinski, thus indicating a good oral bioavailability during drug administration and a desirable profile as new drug candidates. Based on our in silico study, we synthesized nine novel selenoglycolicamides and characterized them using IR, ${ }^{1} \mathrm{H}$ and ${ }^{13} \mathrm{C}$ NMR spectroscopic techniques. All compounds were evaluated in vitro against different fungi and bacteria. In the antifungal activity study, only two of the nine compounds showed inhibition against the strains; the 7a compound demonstrated inhibition against the fungi of the genus Candida albicans and Candida tropicalis, with

Table 3. Minimum inhibitory concentrations (MIC) of the selenoglycolicamides against strains of Candida

\begin{tabular}{|c|c|c|c|c|}
\hline \multirow{3}{*}{ Compound } & \multicolumn{4}{|c|}{ Minimum inhibitory concentration / $\left(\mu \mathrm{g} \mathrm{mL} \mathrm{m}^{-1}\right)$} \\
\hline & \multicolumn{4}{|c|}{ Candida strains } \\
\hline & $\begin{array}{c}\text { C. albicans } \\
\text { ATCC-76485 }\end{array}$ & $\begin{array}{l}\text { C. albicans } \\
\text { LM-5 }\end{array}$ & $\begin{array}{c}\text { C. tropicalis } \\
\text { ATCC-13803 }\end{array}$ & $\begin{array}{l}\text { C. tropicalis } \\
\text { LM-96 }\end{array}$ \\
\hline $7 \mathbf{a}$ & 1024 & 1024 & 1024 & 1024 \\
\hline $7 \mathbf{b}$ & + & + & + & + \\
\hline $7 \mathrm{c}$ & + & + & + & + \\
\hline 7d & + & + & + & + \\
\hline $7 e$ & + & + & + & + \\
\hline $7 \mathbf{f}$ & + & + & + & + \\
\hline $7 g$ & + & + & + & + \\
\hline $7 \mathbf{h}$ & + & + & + & + \\
\hline $7 \mathbf{i}$ & + & + & 512 & 512 \\
\hline Yeast control & + & + & + & + \\
\hline Control of culture medium & - & - & - & - \\
\hline Nystatin & - & - & - & - \\
\hline
\end{tabular}

-: there was no growth of the microorganism; +: growth of the microorganism. 
an MIC of $1024 \mu \mathrm{g} \mathrm{mL} L^{-1}$, and the $7 \mathbf{i}$ compound presented an inhibition against the fungi of the genus Candida tropicalis, with an MIC of $512 \mu \mathrm{g} \mathrm{mL}{ }^{-1}$. In the antibacterial activity study, of the nine compounds, only $\mathbf{7 a}, \mathbf{7} \mathbf{f}$ and $7 \mathbf{i}$ presented satisfactory antibacterial activity, with an MIC $\leq 64 \mu \mathrm{g} \mathrm{mL}^{-1}$, being more potent than the standard drug chloramphenicol. Future studies will involve syntheses of new derivatives to carry out studies of the substances as antibiotic-resistant bacterial resistance modulators.

\section{Experimental}

\section{Chemistry}

All used reagents and solvents were purchased from commercial sources (Sigma-Aldrich) and used without further purification. The progress of the reactions was monitored by thin layer chromatography (TLC) on silica gel plates. The purification of the compounds was performed by recrystallization in ethanol and confirmed by determining the melting range on an MQAPF-302 hotplate (Microquímica). The structures of the new compounds 7a-j were confirmed by elemental analysis on Carlo Erba EA1110 elemental analyzer. The IR spectra were obtained on a Shimadzu model IR Prestige-21 FTIR spectrometer using $\mathrm{KBr}$ pellets. ${ }^{1} \mathrm{H}$ and ${ }^{13} \mathrm{C}$ NMR spectra were obtained on two different machines: a Varian $200 \mathrm{NMR}(200 \mathrm{MHz}$ for ${ }^{1} \mathrm{H}$ and $50 \mathrm{MHz}$ for ${ }^{13} \mathrm{C}$ ) and Varian $500 \mathrm{NMR}(500 \mathrm{MHz}$ for ${ }^{1} \mathrm{H}$ and $126 \mathrm{MHz}$ for ${ }^{13} \mathrm{C}$ ). Deuterated chloroform $\left(\mathrm{CDCl}_{3}\right)$ and deuterated dimethyl sulfoxide (DMSO- $\left.d_{6}\right)$ were used as solvent, and tetramethylsilane (TMS) was used for the internal standard. Chemical shifts $(\delta)$ were measured in parts per million (ppm), and the coupling constants $(J)$, in hertz $(\mathrm{Hz})$.

General procedure for the preparation of $\alpha$-chloro$\mathrm{N}$-arylacetamide $(\mathbf{2 a}-\mathrm{i})^{29}$

To the mixture of substituted aromatic amine $(0.020 \mathrm{~mol})$ and $\mathrm{Et}_{3} \mathrm{~N}(0.024 \mathrm{~mol})$, solubilized in $20 \mathrm{~mL}$ of $\mathrm{CH}_{2} \mathrm{Cl}_{2}$ at a temperature of $0{ }^{\circ} \mathrm{C}$, maintained by an ice bath, 2-chloroacetyl chloride $(0.024 \mathrm{~mol})$ was slowly added. The ice bath was then removed, and the reaction stayed under agitation for $6 \mathrm{~h}$ at room temperature. The reaction mixture was monitored by TLC (hexane/methyl acetate 1:1). At the end of reaction, the reaction mixture was concentrated at reduced pressure and cold water was added to the reaction mixture, causing the formation of a solid. The solid was then filtered and washed with cold water $(3 \times 20 \mathrm{~mL})$, and the final product was purified by recrystallization with an ethanol/water (1:1) mixture.
$\alpha$-Chloro- $N$-phenylacetamide (2a)

Yield: 93\%, mp 133-135 ${ }^{\circ} \mathrm{C}$; ${ }^{1} \mathrm{H}$ NMR $(200 \mathrm{MHz}$, $\left.\mathrm{CDCl}_{3}\right) \delta 4.16\left(\mathrm{~s}, 2 \mathrm{H}, \mathrm{CH}_{2}\right), 7.15$ (t, 1H, H-Ar), 7.33 (t, 2H, H-Ar), 7.52 (d, 2H, H-Ar), 8.28 (s, 1H, NH); ${ }^{13} \mathrm{C} \mathrm{NMR}$ $\left(50 \mathrm{MHz}, \mathrm{CDCl}_{3}\right) \delta 164.0,136.77,129.2,125.35,120.27$, 43.00; IR (KBr) v / cm ${ }^{-1} 3267,3205,3143(\mathrm{NH}), 3098$, $3049\left(\mathrm{CH}_{\text {Ar. }}\right), 2947,2862\left(\mathrm{CH}_{\text {Alip. }}\right), 1672(\mathrm{C}=\mathrm{O}), 1604$, $1496\left(\mathrm{C}=\mathrm{C}_{\mathrm{Ar}}\right), 1290,1250(\mathrm{C}-\mathrm{Cl}), 1078,858\left(\mathrm{CH}_{\mathrm{Ar}}\right), 750$ $(\mathrm{NH}), 557,499\left(\mathrm{C}-\mathrm{C}_{\mathrm{Ar}}\right)$.

$\alpha$-Chloro- $N$-( $p$-nitrophenyl)acetamide (2b)

Yield: $85 \%$, mp $188-190{ }^{\circ} \mathrm{C}$; ${ }^{1} \mathrm{H}$ NMR $(200 \mathrm{MHz}$, DMSO- $d_{6}$ ) $\delta 4.36$ (s, 2H, $\mathrm{CH}_{2}$ ), 7.85 (d, 2H, H-Ar), 8.26 (d, 2H, Ar-H), 10.93 (s, 1H, NH); ${ }^{13} \mathrm{C}$ NMR $(50 \mathrm{MHz}$, DMSO- $d_{6}$ ) $\delta 165.6,144.6,142.6,125.07,119.1,43.6$; IR $(\mathrm{KBr}) v / \mathrm{cm}^{-1} 3277,3227,3163(\mathrm{NH}), 3109,3070\left(\mathrm{CH}_{\mathrm{Ar}}\right)$, 2939, $2825\left(\mathrm{CH}_{\text {Alip }}\right), 1688(\mathrm{C}=\mathrm{O}), 1624,1506\left(\mathrm{C}=\mathrm{C}_{\mathrm{Ar}}\right), 1597$, $1570,1338\left(\mathrm{NO}_{2}\right), 1294,1255(\mathrm{C}-\mathrm{Cl}), 1172,869,850(\mathrm{C}-\mathrm{N}$ of $\left.\mathrm{ArNO}_{2}\right), 1111,829\left(\mathrm{CH}_{\mathrm{Ar}}\right), 748(\mathrm{NH}), 526\left(\mathrm{C}-\mathrm{C}_{\mathrm{Ar}}\right)$.

$\alpha$-Chloro- $N$-( $p$-ethylphenyl)acetamide (2c)

Yield: 92\%, mp 140-142 ${ }^{\circ} \mathrm{C} ;{ }^{1} \mathrm{H}$ NMR $(200 \mathrm{MHz}$, $\left.\mathrm{CDCl}_{3}\right) \delta 1.22\left(\mathrm{t}, 3 \mathrm{H}, \mathrm{CH}_{3}\right), 2.63\left(\mathrm{q}, 2 \mathrm{H}, \mathrm{CH}_{2}\right), 4.17(\mathrm{~s}, 2 \mathrm{H}$, $\mathrm{CH}_{2}$ ), 7.18 (d, 2H, H-Ar), 7.44 (d, 2H, H-Ar), 8.23 (s, 1H, $\mathrm{NH}) ;{ }^{13} \mathrm{C}$ NMR (50 MHz, DMSO- $\left.d_{6}\right) \delta 163.89,141.53$, $134.37,128.56,120.45,43.0,28.45,15.7 ; \mathrm{IR}(\mathrm{KBr}) v / \mathrm{cm}^{-1}$ 3308, 3273, $3201(\mathrm{NH}), 3088,2965\left(\mathrm{CH}_{\mathrm{Ar}}\right), 2964,2868$ $\left(\mathrm{CH}_{\text {Alip. }}\right), 1668(\mathrm{C}=\mathrm{O}), 1614,1512\left(\mathrm{C}=\mathrm{C}_{\mathrm{Ar} .}\right), 1292,1254$ $(\mathrm{C}-\mathrm{Cl}), 1118,864\left(\mathrm{CH}_{\mathrm{Ar}}\right), 740(\mathrm{NH}), 540,487\left(\mathrm{C}-\mathrm{C}_{\mathrm{Ar}}\right)$.

$\alpha$-Chloro- $N$ - $(p$-methylphenyl)acetamide (2d)

Yield: $95 \%, \mathrm{mp} 182-184{ }^{\circ} \mathrm{C} ;{ }^{1} \mathrm{HNMR}\left(200 \mathrm{MHz}, \mathrm{CDCl}_{3}\right)$ $\delta 2.33$ (s, 3H, $\left.\mathrm{CH}_{3}\right), 4.17$ (s, 2H, $\mathrm{CH}_{2}$ ), 7.15 (d, 2H, H-Ar), 7.42 (d, 2H, H-Ar), 8.21 (s, $1 \mathrm{H}, \mathrm{NH}) ;{ }^{13} \mathrm{C}$ NMR $(50 \mathrm{MHz}$, DMSO- $\left.d_{6}\right) \delta 163.86,135.1,134.2,129.7,120.3,42.66,21.0$; $\operatorname{IR}(\mathrm{KBr}) v / \mathrm{cm}^{-1} 3307,3273,3203(\mathrm{NH}), 3134,3089\left(\mathrm{CH}_{\mathrm{Ar}}\right)$, $2953\left(\mathrm{CH}_{\text {Alip. }}\right), 1674(\mathrm{C}=\mathrm{O}), 1616,1552\left(\mathrm{C}=\mathrm{C}_{\mathrm{Ar}}\right), 1292,1252$ $(\mathrm{C}-\mathrm{Cl}), 114,864\left(\mathrm{CH}_{\mathrm{Ar}}\right), 748(\mathrm{NH}), 505\left(\mathrm{C}-\mathrm{C}_{\mathrm{Ar}}\right)$.

$\alpha$-Chloro- $N$-( $p$-bromophenyl)acetamide (2e)

Yield: $85 \%, \mathrm{mp} 184-186{ }^{\circ} \mathrm{C}$; ${ }^{1} \mathrm{H}$ NMR $(200 \mathrm{MHz}$, DMSO- $\left.d_{6}\right) \delta 4.27$ (s, 2H, $\mathrm{CH}_{2}$ ), 7.55 (m, 4H, H-Ar), 10.45 $(\mathrm{s}, 1 \mathrm{H}, \mathrm{NH}) ;{ }^{13} \mathrm{C}$ NMR $\left(50 \mathrm{MHz}, \mathrm{DMSO}-d_{6}\right) \delta 164.8$, 137.8, 131.7, 121.28, 115.5, 43.56; IR (KBr) $v / \mathrm{cm}^{-1} 3263$, $3194(\mathrm{NH}), 3124,3076\left(\mathrm{CH}_{\text {Ar. }}\right), 2999,2953\left(\mathrm{CH}_{\text {Alip }}\right), 1670$ $(\mathrm{C}=\mathrm{O}), 1610,1550\left(\mathrm{C}=\mathrm{C}_{\mathrm{Ar}}\right), 1281,1246(\mathrm{C}-\mathrm{Cl}), 1188$ (C-Br), 1072, $860\left(\mathrm{CH}_{\mathrm{Ar}}\right), 736(\mathrm{NH}), 497\left(\mathrm{C}-\mathrm{C}_{\mathrm{Ar}}\right)$.

$\alpha$-Chloro- $N$-( $p$-chlorophenyl)acetamide (2f)

Yield: 79\%, mp 170-172 ${ }^{\circ} \mathrm{C} ;{ }^{1} \mathrm{H}$ NMR $(200 \mathrm{MHz}$, DMSO- $\left.d_{6}\right) \delta 4.27$ (s, 2H, $\mathrm{CH}_{2}$ ), 7.40 (d, 2H, H-Ar), 7.63 
(d, 2H, H-Ar), 10.45 (s, 1H, NH); ${ }^{13} \mathrm{C}$ NMR $(50 \mathrm{MHz}$, DMSO- $\left.d_{6}\right) \delta 164.8,137.4,128.8,127.4,120.9,43.5$; IR $(\mathrm{KBr}) v / \mathrm{cm}^{-1} 3264,3198(\mathrm{NH}), 3128,3080\left(\mathrm{CH}_{\mathrm{Ar}}\right), 3003$, $2951\left(\mathrm{CH}_{\text {Alip }}\right), 1668(\mathrm{C}=\mathrm{O}), 1612,1551\left(\mathrm{C}=\mathrm{C}_{\mathrm{Ar} .}\right), 1281$, $1246(\mathrm{C}-\mathrm{Cl}), 1095(\mathrm{C}-\mathrm{Cl}$ of $\mathrm{ArCl}), 1010,862\left(\mathrm{CH}_{\mathrm{Ar}}\right), 737$ $(\mathrm{NH}), 567,501\left(\mathrm{C}-\mathrm{C}_{\mathrm{Ar}}\right)$.

\section{$\alpha$-Chloro- $N$-( $p$-isopropylphenyl)acetamide (2g)}

Yield: 77\%, mp 141-143 ${ }^{\circ} \mathrm{C}$; ${ }^{1} \mathrm{H}$ NMR $(200 \mathrm{MHz}$, DMSO- $\left.d_{6}\right) \delta 1.24\left(\mathrm{~d}, 6 \mathrm{H}, \mathrm{CH}_{3}\right), 2.90(\mathrm{~s}, 1 \mathrm{H}, \mathrm{CH}), 4.17(\mathrm{~s}$, 2H, $\mathrm{CH}_{2}$ ), 7.23 (d, 2H, H-Ar), 7.45 (d, 2H, H-Ar), 8.21 (s, $1 \mathrm{H}, \mathrm{NH}) ;{ }^{13} \mathrm{C}$ NMR $\left(50 \mathrm{MHz}, \mathrm{DMSO}-d_{6}\right) \delta 163.87,146.19$, 134.4, 127.16, 120.47, 43.0, 33.76, 24.1; IR (KBr) $v / \mathrm{cm}^{-1}$ $3271,3199(\mathrm{NH}), 3130\left(\mathrm{CH}_{\text {Ar. }}\right), 2960,2870\left(\mathrm{CH}_{\text {Alip }}\right), 1674$ $(\mathrm{C}=\mathrm{O}), 1612,1548\left(\mathrm{C}=\mathrm{C}_{\mathrm{Ar}}\right), 1282,1250(\mathrm{C}-\mathrm{Cl}), 1300$, $1282\left(i \mathrm{CH}_{\text {Alip }}\right), 1016,837\left(\mathrm{CH}_{\mathrm{Ar}}\right), 779(\mathrm{NH}), 534\left(\mathrm{C}-\mathrm{C}_{\mathrm{Ar}}\right)$.

\section{$\alpha$-Chloro- $N$-(p-methoxyphenyl)acetamide (2h)}

Yield: $85 \%$, mp $119-120{ }^{\circ} \mathrm{C}$; ${ }^{1} \mathrm{H}$ NMR $(200 \mathrm{MHz}$, DMSO- $\left.d_{6}\right) \delta 3.79\left(\mathrm{~s}, 3 \mathrm{H}, \mathrm{OCH}_{3}\right), 4.17\left(\mathrm{~s}, 2 \mathrm{H}, \mathrm{CH}_{2}\right), 6.88(\mathrm{~d}$, $2 \mathrm{H}, \mathrm{H}-\mathrm{Ar}), 7.43$ (d, 2H, H-Ar), $8.20(\mathrm{~s}, 1 \mathrm{H}, \mathrm{NH}) ;{ }^{13} \mathrm{C} \mathrm{NMR}$ $\left(50 \mathrm{MHz}, \mathrm{DMSO}-d_{6}\right) \delta 163.89,157.16,129.79,122.2$, 114.3, 55.6, 42.97; IR (KBr) v / cm ${ }^{-1} 3296,3199(\mathrm{NH})$, 3136, $3072\left(\mathrm{CH}_{\mathrm{Ar}}\right), 2956,2835\left(\mathrm{CH}_{\text {Alip. }}\right), 1666(\mathrm{C}=\mathrm{O}), 1605$, $1548\left(\mathrm{C}=\mathrm{C}_{\mathrm{Ar}}\right), 1346,1301(\mathrm{C}-\mathrm{Cl}), 1248,1113(\mathrm{C}-\mathrm{O}-\mathrm{C})$, 1029, $831\left(\mathrm{CH}_{\mathrm{Ar}}\right), 788(\mathrm{NH}), 582,532\left(\mathrm{C}-\mathrm{C}_{\mathrm{Ar}}\right)$.

\section{$\alpha$-Chloro- $N$ - $(m$-nitro- $p$-chlorophenyl)acetamide (2i)}

Yield: $80 \%$, mp $120-122{ }^{\circ} \mathrm{C}$; ${ }^{1} \mathrm{H}$ NMR $(200 \mathrm{MHz}$, DMSO- $\left.d_{6}\right) \delta 4.32$ (s, $2 \mathrm{H}, \mathrm{CH}_{2}$ ), 7.74 (d, $\left.1 \mathrm{H}, \mathrm{H}-\mathrm{Ar}\right), 7.81$ (dd, 1H, H-Ar), 8.40 (d, 1H, H-Ar), 10.87 (s, 1H, NH); ${ }^{13} \mathrm{C}$ NMR (50 MHz, DMSO- $d_{6}$ ) $\delta 165.5,147.28,138.3$, 132.2, 124.27, 119.16, 115.76, 43.4; IR (KBr) $v / \mathrm{cm}^{-1} 3313$, $3269(\mathrm{NH}), 3122,3094\left(\mathrm{CH}_{\text {Ar. }}\right), 2945,2881\left(\mathrm{CH}_{\text {Alip. }}\right), 1691$ $(\mathrm{C}=\mathrm{O}), 1605,1544\left(\mathrm{C}=\mathrm{C}_{\mathrm{Ar}}\right), 1483,1404,1344\left(\mathrm{NO}_{2}\right), 1300$, $1265(\mathrm{C}-\mathrm{Cl}), 1045,831\left(\mathrm{CH}_{\mathrm{Ar}}\right), 895\left(\mathrm{C}-\mathrm{N}\right.$ of $\left.\mathrm{ArNO}_{2}\right), 785$ $(\mathrm{NH}), 559\left(\mathrm{C}-\mathrm{C}_{\mathrm{Ar}}\right)$.

\section{General procedure for the preparation selenoglycolicamides ${ }^{28}$}

Sodium borohydride $(0.0139 \mathrm{~mol})$ was dissolved in $6 \mathrm{~mL}$ of water and added, slowly, under a selenium suspension $(0.0063 \mathrm{~mol})$ in $6 \mathrm{~mL}$ of water, contained in a flask of $50 \mathrm{~mL}$. The reaction was exothermic, and a liberation of hydrogen gas was observed. Then (in situ), the aroyl chloride $(0.0063 \mathrm{~mol})$ was added, slowly, at a temperature of $30{ }^{\circ} \mathrm{C}$. After $60 \mathrm{~min}$ of agitation at room temperature, $\alpha$-chloro- $N$-arylacetamides $(0.0063 \mathrm{~mol})$ in a small quantity of acetone were added, slowly, to the solution. The formation of a precipitate was observed at the end of reaction. The mixture was agitated for another $2 \mathrm{~h}$ at room temperature. Then, the reaction mixture was subjected to extraction with dichloromethane $(3 \times 25 \mathrm{~mL})$. The organic phase was filtered on a porcelain plate containing silica gel and then concentrated under reduced pressure, providing the final products that were recrystallized in ethanol.

\section{$\mathrm{N}$-Phenylbenzoselenoglycolicamide (7a)}

Yield: $75 \%$, white solid, mp $132-133{ }^{\circ} \mathrm{C}$; ${ }^{1} \mathrm{H}$ NMR $\left(200 \mathrm{MHz}, \mathrm{CDCl}_{3}\right) \delta 8.36(\mathrm{~s}, 1 \mathrm{H}, \mathrm{NH}), 7.92(\mathrm{~d}, J 7.4 \mathrm{~Hz}$, 2H, H-3 and H-3'), 7.65 (t, J 7.3 Hz, 1H, H-5), 7.54-7.45 (m, 4H, H-4, H-4', H-9 and H-13), 7.30 (t, J 7.3 Hz, 2H, $\mathrm{H}-10$ and H-12), 7.08 (t, $J .3 \mathrm{~Hz}, 1 \mathrm{H}, \mathrm{H}-11), 3.78$ (s, 2H, $\mathrm{H}-6) ;{ }^{13} \mathrm{C}$ NMR (50 MHz, $\left.\mathrm{CDCl}_{3}\right) \delta 196.74$ (C-1), 137.94 (C-2), 129.16 (C-3 and C-3'), 129.09 (C-4 and C-4'), 134.73 (C-5), 28.27 (C-6), 168.25 (C-7), 138.06 (C-8), 119.91 (C-9 and C-13), 127.38 (C-10 and C-12), 124.44 (C-11); IR (KBr) v / cm $3292(\mathrm{~N}-\mathrm{H}), 3053$ (=C-H, Ar), 1654 (-N-CO), 1674 (-Se-CO), 1596 and 1444 (C=C, Ar). Anal. calcd. for $\mathrm{C}_{15} \mathrm{H}_{13} \mathrm{NO}_{2} \mathrm{Se}: \mathrm{C}, 56.61 ; \mathrm{H}, 4.12 ; \mathrm{N}, 4.40$; found: C, 55.30; H, 3.90; N, 4.84 .

\section{$\mathrm{N}$-(4-Nitrophenyl)benzoselenoglycolicamide (7b)}

Yield: $70 \%$, white solid, mp 192-193 ${ }^{\circ} \mathrm{C}$; ${ }^{1} \mathrm{H}$ NMR $\left(200 \mathrm{MHz}, \mathrm{CDCl}_{3}\right) \delta 8.82(\mathrm{~s}, 1 \mathrm{H}, \mathrm{NH}), 8.19(\mathrm{~d}, J 9.2 \mathrm{~Hz}$, $2 \mathrm{H}, \mathrm{H}-10$ and $\mathrm{H}-12), 7.94(\mathrm{~d}, J 7.1 \mathrm{~Hz}, 2 \mathrm{H}, \mathrm{H}-3$ and $\mathrm{H}-3^{\prime}$ ), 7.73-7.66 (m, 3H, H-5 to H-9 and $\mathrm{H}-13$ ), 7.52 (t, $J 7.5 \mathrm{~Hz}, 2 \mathrm{H}, \mathrm{H}-4$ and $\mathrm{H}-4$ '), $3.80(\mathrm{~s}, \mathrm{H}, 2 \mathrm{H}, \mathrm{H}-6)$; ${ }^{13} \mathrm{C}$ NMR (50 MHz, $\left.\mathrm{CDCl}_{3}\right) \delta 197.59(\mathrm{C}-1), 137.66(\mathrm{C}-2)$, 129.38 (C-3 and C-3'), 127.7 (C-4 and C-4'), 135.16 (C-5), 28.02 (C-6), 168.83 (C-7), 143.91 (C-8), 119.22 (C-9 and C-13), 125.2 (C-10 and C-12), 143.66 (C-11); IR (KBr) v / cm ${ }^{-1} 3261(\mathrm{~N}-\mathrm{H}), 3207-3067$ (=C-H, Ar), 1670 (-Se-CO and $-\mathrm{N}-\mathrm{CO}$ overlapping), 1564 and 1404 $(\mathrm{C}=\mathrm{C}, \mathrm{Ar}), 1510$ and $1342\left(\mathrm{NO}_{2}\right), 852(=\mathrm{C}-\mathrm{H}, \mathrm{Ar})$. Anal. calcd. for $\mathrm{C}_{15} \mathrm{H}_{12} \mathrm{~N}_{2} \mathrm{O}_{4} \mathrm{Se}: \mathrm{C}, 49.60 ; \mathrm{H}, 3.33 ; \mathrm{N}, 7.71$; found: C, 48.68; H, 3.19; N, 7.99.

\section{$\mathrm{N}$-(4-Ethylphenyl)benzoselenoglycolicamide (7c)}

Yield: $72 \%$, white solid, mp $124-125{ }^{\circ} \mathrm{C}$; ${ }^{1} \mathrm{H}$ NMR $\left(200 \mathrm{MHz}, \mathrm{CDCl}_{3}\right) \delta 8.30(\mathrm{~s}, 1 \mathrm{H}, \mathrm{NH}), 7.91(\mathrm{~d}, J 7.6 \mathrm{~Hz}$, 2H, H-3 and H-3'), 7.63 (t, J 7.4 Hz, 1H, H-5), 7.52-7.66 (m, 4H, H-4, H-4', H-9 and H-13), 7.12 (d, J 8.4 Hz, 2H, $\mathrm{H}-10$ and $\mathrm{H}-12$ ), 3.78 (s, 2H, H-6), 2.59 (q, $2 \mathrm{H}, \mathrm{CH}_{2} \mathrm{CH}_{3}$ ), $1.19\left(\mathrm{t}, 3 \mathrm{H}, \mathrm{CH}_{2} \mathrm{C}_{3}\right) ;{ }^{13} \mathrm{C} \mathrm{NMR}\left(50 \mathrm{MHz}, \mathrm{CDCl}_{3}\right) \delta 196.62$ (C-1), 137.98 (C-2), 129.21 (C-3 and C-3'), 128.37 (C-4 and C-4'), 134.69 (C-5), 28.27 (C-6), 168.11 (C-7), 135.67 (C-8), 120.04 (C-9 and C-13), 127.55 (C-10 and C-12), $140.58(\mathrm{C}-11), 28.43\left(\mathrm{CH}_{2}\right), 15.83\left(\mathrm{CH}_{3}\right) ; \mathrm{IR}(\mathrm{KBr}) v / \mathrm{cm}^{-1}$ $3284(\mathrm{~N}-\mathrm{H}), 3068$ (=C-H, Ar), 1674 (-Se-CO), 1651 $(-\mathrm{N}-\mathrm{CO}), 1593$ and 1413 (C=C, Ar), 883 (=C-H, Ar), 767 
(N-H). Anal. calcd. for $\mathrm{C}_{17} \mathrm{H}_{17} \mathrm{NO}_{2} \mathrm{Se}: \mathrm{C}, 58.96 ; \mathrm{H}, 4.95$; $\mathrm{N}, 4.04$; found: C, 59.78; H, 4.95; N, 4.90 .

$\mathrm{N}$-(4-Methylphenyl)benzoselenoglycolicamide (7d)

Yield: 77\%, white solid, mp 132-134 ${ }^{\circ} \mathrm{C} ;{ }^{1} \mathrm{H}$ NMR $\left(200 \mathrm{MHz}, \mathrm{CDCl}_{3}\right) \delta 8.28(\mathrm{~s}, 1 \mathrm{H}, \mathrm{NH}), 7.92(\mathrm{~d}, J 7.6 \mathrm{~Hz}$, 2H, H-3 and H-3'), 7.65 (t, J 7.4 Hz, 1H, H-5), 7.49 (t, $J$ 7.4 Hz, 2H, H-4 and H-4'), 7.40 (d, J 8.4 Hz, 2H, H-9 and $\mathrm{H}-13$ ), 7.10 (d, J 8.4 Hz, 2H, H-10 and H-12), 3.77 (s, 2H, H-6), 2.29 (s, 3H, $\left.\underline{\mathrm{CH}}_{3}\right) ;{ }^{13} \mathrm{C} \mathrm{NMR} \mathrm{(50} \mathrm{MHz,} \mathrm{CDCl}_{3}$ ) $\delta 196.64$ (C-1), 135.49 (C-2), 129.54 (C-3 and C-3'), 129.22 (C-4 and C-4'), 134.7 (C-5), 28.27 (C-6), 168.1 (C-7), 134.09 (C-8), 119.95 (C-9 and C-13), 127.56 (C-10 and C-12), 137.99 (C-11), $20.99\left(\mathrm{CH}_{3}\right)$; IR (KBr) v / cm ${ }^{-1}$ 3269.34 (N-H), 3037.89 (=C-H, Ar), 1674 (-Se-CO), 1651 (-N-CO), 1595 and 1402 (C=C, Ar), 889 (=C-H, Ar). Anal. calcd. for $\mathrm{C}_{16} \mathrm{H}_{15} \mathrm{NO}_{2} \mathrm{Se}$ : C, 57.84; $\mathrm{H}, 4.55 ; \mathrm{N}, 4.22$; found: C, 58.37; H, 4.52; N, 5.01.

\section{N-(4-Bromophenyl)benzoselenoglycolicamide (7e)}

Yield: $73 \%$, white solid, mp $165-167{ }^{\circ} \mathrm{C} ;{ }^{1} \mathrm{H}$ NMR $\left(200 \mathrm{MHz}, \mathrm{CDCl}_{3}\right) \delta 8.40(\mathrm{~s}, 1 \mathrm{H}, \mathrm{NH}), 7.92$ (d, J 7.6 Hz, 2H, H-3 and H-3'), 7.67 (t, J 6.9 Hz, 1H, H-5), 7.50 (t, J 7.5 Hz, 2H, H-4 and H-4'), 7.42 (s, 4H, H-9, H-10, H-12 and $\mathrm{H}-13$ ), 3.77 (s, 2H, H-6); ${ }^{13} \mathrm{C} \mathrm{NMR} \mathrm{(50} \mathrm{MHz,} \mathrm{CDCl}_{3}$ ) d 197.03 (C-1), 137.15 (C-2), 129.28 (C-3 and C-3'), 127.62 (C-4 and C-4'), 134.9 (C-5), 28.14 (C-6), 168.35 (C-7), 137.83 (C-8), 121.41 (C-9 and C-13), 132.02 (C-10 and C-12), 117.0 (C-11); IR (KBr) v / cm $3263(\mathrm{~N}-\mathrm{H})$, 3182-3059 (=C-H, Ar), 1672 (-Se-CO), 1651 (-N-CO), 1537 and 1487 ( $\mathrm{C}=\mathrm{C}, \mathrm{Ar}), 815$ (=C-H, Ar). Anal. calcd. for $\mathrm{C}_{15} \mathrm{H}_{12} \mathrm{BrNO}_{2} \mathrm{Se}$ : C, 45.37; H, 3.05; N, 3.53; found: $\mathrm{C}$, 46.08; H, 3.03; N, 4.05.

\section{$\mathrm{N}$-(4-Chlorophenyl)benzoselenoglycolicamide (7f)}

Yield: 68\%, white solid, mp $152-154{ }^{\circ} \mathrm{C} ;{ }^{1} \mathrm{H}$ NMR $\left(200 \mathrm{MHz}, \mathrm{CDCl}_{3}\right) \delta 8.38(\mathrm{~s}, 1 \mathrm{H}, \mathrm{NH}), 7.92$ (d, J $7.9 \mathrm{~Hz}$, 2H, H-3 and H-3'), 7.66 (t, J 7.4 Hz, 1H, H-5), 7.51-7.49 (m, 4H, H-4, H-4', H-9 and H-13), 7.26 (d, 2H, J 8.4 Hz, $\mathrm{H}-10$ and H-12), 3.77 (s, 2H, H-6); ${ }^{13} \mathrm{C} \mathrm{NMR}(50 \mathrm{MHz}$, $\left.\mathrm{CDCl}_{3}\right) \delta 196.92(\mathrm{C}-1), 137.93(\mathrm{C}-2), 129.29$ (C-3 and C-3'), 129.08 (C-4 and C-4'), 134.86 (C-5), 28.15 (C-6), 168.28 (C-7), 136.7 (C-8), 121.12 (C-9 and C-13), 127.62 (C-10 and C-12), 129.42 (C-11); IR (KBr) v / $\mathrm{cm}^{-1} 3278$ (N-H), 3122-3068 (=C-H, Ar), 1674 (-Se-CO), 1654 (-N-CO), 1544 and $1400(\mathrm{C}=\mathrm{C}, \mathrm{Ar}), 833$ (=C-H, Ar). Anal. calcd. for $\mathrm{C}_{15} \mathrm{H}_{12} \mathrm{ClNO}_{2} \mathrm{Se}$ : C, 51.08; H, 3.48; N, 3.97; found: C, 51.98; H, 3.43; N, 4.10.

\section{$\mathrm{N}$-(4-Isopropylphenyl)benzoselenoglycolicamide (7g)}

Yield: $70 \%$, white solid, mp $108-110{ }^{\circ} \mathrm{C} ;{ }^{1} \mathrm{H}$ NMR $\left(200 \mathrm{MHz}, \mathrm{CDCl}_{3}\right) \delta 8.25(\mathrm{~s}, 1 \mathrm{H}, \mathrm{NH}), 7.92(\mathrm{~d}, J 7.5 \mathrm{~Hz}$, 2H, H-3 and H-3'), 7.64 (t, J 7.4 Hz, 1H, H-5), 7.49 (t, $J 7.8 \mathrm{~Hz}, 2 \mathrm{H}, \mathrm{H}-4$ and H-4'), 7.43 (d, J $8.4 \mathrm{~Hz}, 2 \mathrm{H}, \mathrm{H}-9$ and H-13), 7.16 (d, J 8.4 Hz, 2H, H-10 and H-12), 3.77 (s, 2H, H-6), 2.86 (sep, 1H, $\left.\underline{\mathrm{H}}\left(\mathrm{CH}_{3}\right)_{2}\right), 1.21$ (d, 6H, $\left.\mathrm{CH}\left(\mathrm{CH}_{3}\right)_{2}\right)$; ${ }^{13} \mathrm{C} \mathrm{NMR}\left(50 \mathrm{MHz}, \mathrm{CDCl}_{3}\right) \delta 196.63$ (C-1), 138.07 (C-2), 129.23 (C-3 and C-3'), 127.58 (C-4 and C-4'), 134.7 (C-5), 28.29 (C-6), 168.1 (C-7), 135.78 (C-8), 120.1 (C-9 and C-13), 126.96 (C-10 and C-12), 145.26 (C-11), 33.74 $\left(\underline{\mathrm{CH}}\left(\mathrm{CH}_{3}\right)_{2}\right), 24.1\left(\mathrm{CH}\left(\underline{\mathrm{CH}}_{3}\right)_{2}\right)$; IR $(\mathrm{KBr}) \vee / \mathrm{cm}^{-1} 3282$ (N-H), 3124-3061 (=C-H, Ar), 1674 (-Se-CO), 1656 (-N-CO), 1600-1446 (C=C, Ar), 889 (=C-H, Ar), 767 $(\mathrm{N}-\mathrm{H})$. Anal. calcd. for $\mathrm{C}_{18} \mathrm{H}_{19} \mathrm{NO}_{2} \mathrm{Se}$ : C, 60.00; H, 5.32; N, 3.98; found: C, 60.76; H, 5.48; N, 4.55.

\section{$\mathrm{N}$-(4-Methoxyphenyl)benzoselenoglycolicamide (7h)}

Yield: $75 \%$, white solid, mp 139-140 ${ }^{\circ} \mathrm{C}$; ${ }^{1} \mathrm{H}$ NMR $\left(200 \mathrm{MHz}, \mathrm{CDCl}_{3}\right) \delta 8.24$ (s, 1H, NH), 7.92 (d, J 7.1 Hz, 2H, H-3 and H-3'), 7.65 (t, J 7.1 Hz, 1H, H-5), 7.53-7.49 (m, 4H, H-4, H-4', H-9 and H-13), 6.48 (d, J 9.0 Hz, 2H, $\mathrm{H}-10$ and $\mathrm{H}-12), 3.77$ (s, 5H, H-6 and $\left.\mathrm{OCH}_{3}\right) ;{ }^{13} \mathrm{C} \mathrm{NMR}$ $\left(50 \mathrm{MHz}, \mathrm{CDCl}_{3}\right) \delta 196.37$ (C-1), 138.03 (C-2), 129.19 (C-3 and C-3'), 127.53 (C-4 and C-4'), 134.63 (C-5), 29.22 (C-6), 168.0 (C-7), 131.19 (C-8), 121.74 (C-9 and C-13), 114.22 (C-10 and C-12), 156.58 (C-11), $55.57\left(\mathrm{OCH}_{3}\right)$; IR $(\mathrm{KBr}) v / \mathrm{cm}^{-1} 3282(\mathrm{~N}-\mathrm{H}), 3124-3061$ (=C-H, Ar), 1678 (-Se-CO), 1639 (-N-CO), 1541 (C=C, Ar), 1029 (C-O-C), 883 (=C-H, Ar), $767(\mathrm{~N}-\mathrm{H})$. Anal. calcd. for $\mathrm{C}_{16} \mathrm{H}_{15} \mathrm{NO}_{3} \mathrm{Se}: \mathrm{C}, 55.18 ; \mathrm{H}, 4.34 ; \mathrm{N}, 4.02$; found: $\mathrm{C}$, 54.33; $\mathrm{H}, 4.25 ; \mathrm{N}, 4.44$.

$\mathrm{N}$-(4-Chloro-3-nitrophenyl)benzoselenoglycolicamide (7i)

Yield: $72 \%$, gray solid, mp 132-134 ${ }^{\circ} \mathrm{C} ;{ }^{1} \mathrm{H}$ NMR $\left(200 \mathrm{MHz}, \mathrm{CDCl}_{3}\right) \delta 10.91(\mathrm{~s}, 1 \mathrm{H}, \mathrm{NH}), 8.40(\mathrm{~d}, J 2.2 \mathrm{~Hz}$, 1H, H-9), 7.90 (d, J 7.1 Hz, 2H, H-3 and H-3'), 7.74 (m, $3 \mathrm{H}, \mathrm{H}-5, \mathrm{H}-12$ and H-13), 7.58 (t, J 7.5 Hz, 2H, H-4 and H-4'), 4.01 (s, 2H, H-6); ${ }^{13} \mathrm{C} \mathrm{NMR} \mathrm{(50} \mathrm{MHz,} \mathrm{CDCl}_{3}$ )

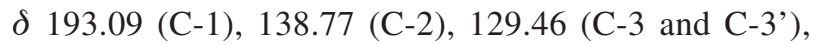
126.92 (C-4 and C-4'), 134.59 (C-5), 29.02 (C-6), 167.9 (C-7), 137.58 (C-8), 115.43 (C-9), 147.26 (C-10), 118.71 (C-11), 123.97 (C-12), 132.10 (C-13); IR (KBr) v / cm ${ }^{-1}$ 3238 (N-H), 3101-3059 (=C-H, Ar), 1674 (-Se-CO), 1654 $(-\mathrm{N}-\mathrm{CO}), 1595$ and $1408(\mathrm{C}=\mathrm{C}, \mathrm{Ar}), 1529$ and $1361\left(\mathrm{NO}_{2}\right)$, $1047(\mathrm{C}-\mathrm{Cl}), 835$ (=C-H, Ar), $765(\mathrm{~N}-\mathrm{H})$. Anal. calcd. for $\mathrm{C}_{15} \mathrm{H}_{11} \mathrm{ClN}_{2} \mathrm{O}_{4} \mathrm{Se}: \mathrm{C}, 45.30 ; \mathrm{H}, 2.79 ; \mathrm{N}, 7.04$; found: $\mathrm{C}$, 45.80; H, 2.79; N, 7.47.

Biological activity

Antibacterial activity

Organoselenium compounds were screened in vitro for 
antibacterial activity and antimicrobial modulatory effects in three effluxing strains: SA-1199B, which carries the gene encoding the NorA fluoroquinolone efflux protein; 5,45 RN-4220, which has the pUL5054 plasmid that carries the gene encoding the protein MsrA for macrolide efflux; ${ }^{46}$ and IS-58, which has the efflux protein for tetracycline (TetK). ${ }^{47}$ It was also used a standard strain ATCC 25923, an important strain for the quality test disk diffusion and MIC testing Staphylococcus spp., which does not produce beta-lactamase. All of these strains were cultured on nutrient agar slants (blood agar base (BAB), Difco Laboratories). Before being used, the cells were grown in nutrient broth infusion (brain heart infusion (BHI), Difco Laboratories) for 18-24 h at $37{ }^{\circ} \mathrm{C}$. These strains were provided by Dr Simon Gibbons (University of London). The MICs of organoselenium compounds were determined by microdilution assay using a suspension of ca. $10^{5}$ colony forming unit (CFU) $\mathrm{mL}^{-1}$ and drug concentration range of 512-4 $\mu \mathrm{g} \mathrm{mL}^{-1}$. MIC is defined as the lowest concentration at which no growth is observed. ${ }^{48}$ The results of antibacterial activity are presented in Table 2.

\section{Antifungal activity}

In the antifungal assay of the synthesized compounds, the microorganisms used were Candida albicans (ATCC-76485 and LM-5) and Candida tropicalis (ATCC-13803 and LM-96). They were acquired at the Micoteca of the Mycology Laboratory, Department of Pharmaceutical Sciences (DCF), Health Sciences Center (CCS) at Federal University of Paraíba, Brazil. The fungus strains were maintained in appropriate medium, agar Sabouraud dextrose (ASD, Difco Laboratories), and stored at 4 and $35^{\circ} \mathrm{C}$. The microorganism suspension was prepared according with the $0.5 \mathrm{McFarland}$ scale tube and was adjusted by the use of a spectrophotometer (Leitz-Phtometer 340-800) to $90 \% \mathrm{~T}(530 \mathrm{~nm})$, corresponding to approximately $10^{6} \mathrm{CFU} \mathrm{mL} \mathrm{mL}^{-1} .49-51$ The antifungal tests were performed in Sabouraud dextrose broth (SDB, Difco Laboratories), which was prepared and used according the manufacturer's instructions. The MIC value was determined by the microdilution method using 96-well microtiter plates with "U" bottoms and in duplicate. To each plate well, $100 \mu \mathrm{L}$ of SDB was added in double concentrated liquid medium. Then, $100 \mu \mathrm{L}$ of the product solution (also double concentrated) was distributed in the wells of the first line of the plate. Using serial dilution (proportion of two), concentrations of 1024 to $64 \mu \mathrm{g} \mathrm{mL}^{-1}$ were obtained so that the higher concentrations were in the first line of the plate and the lower concentrations were in the last. Finally, $10 \mu \mathrm{L}$ of inoculum was added to the wells, where each column of the plate referred to a specific strain. The same was done in the culture medium with the fungal drug nystatin $\left(100 \mu \mathrm{g} \mathrm{mL}^{-1}\right)$. The plates were incubated at $37^{\circ} \mathrm{C}$ for $24-48 \mathrm{~h}$. For each strain, the MIC was defined as the minimum concentration capable of inhibiting the fungal growth, by visual observation of the wells, when compared to the control. All of the tests were performed in duplicate, and the results were expressed as the geometric average of the MIC values obtained in the two assays. The antifungal activity results are presented in Table 3.

\section{Supplementary Information}

Supplementary information is available free of charge at http://jbcs.sbq.org.br as PDF file.

\section{Acknowledgments}

This work was supported by the following Brazilian agencies: $\mathrm{CNPq}$ and CAPES.

\section{References}

1. Oliveira, C. S.; Lira. B. F.; Barbosa-Filho, J. M.; Lorenzo, J. G. F.; Menezes, C. P.; Santos, J. M. C. G.; Lima, E. O.; AthaydeFilho, P. F.; J. Braz. Chem. Soc. 2013, 24, 115.

2. Kourtesi, C.; Ball, A. R.; Huang, Y. Y.; Jachak, S. M.; Vera, D. M. A.; Khondkar, P.; Gibbons, S.; Hamblin M. R.; Tegos G. P.; Open Microbiol. J. 2013, 7, 34.

3. Gibbons, S.; Oluwatuyi, M.; Kaatz, G. W.; J. Antimicrob. Chemother. 2003, 51, 13.

4. Gibbons, S.; Moser, E.; Kaatz, G. W.; Planta Med. 2004, 70, 1240.

5. Kaatz, G. W.; Seo, S. M.; Antimicrob. Agents Chemother. 1995, 39, 2650.

6. Hassan, K. A.; Skurray, R. A.; Brown, M. H.; J. Mol. Microbiol. Biotechnol. 2007, 12, 180.

7. Broskey, J.; Coleman, K.; Gwynn, M. N.; Mccloskey, L.; Traini, C.; Voelker, L.; Warren, R.; J. Antimicrob. Chemother. 2000, 45,95 .

8. Mazzariol, A.; Tokue, Y.; Kanegawa, T. M.; Cornalia, G.; Nikaido, H.; Antimicrob. Agents Chemother. 2000, 44, 3441.

9. Payne, D. J.; Gwynn, M. N.; Holmes, D. J.; Pompliano, D. L.; Nat. Rev. Drug Discovery 2007, 6, 29.

10. Fernebro, J.; Drug Resist. Updates 2011, 14, 125.

11. Lynch, A. S.; Biochem. Pharmacol. 2006, 71, 949.

12. Santos, E. A.; Hamel, E.; Bai, R.; Burnett, J. C.; Tozatti, C. S. S.; Bogo, D.; Perdomo, R. T.; Antunes, A. M. M.; Marques, M. M.; Matos, M. F. C.; Lima, D. P.; Bioorg. Med. Chem. Lett. 2013, 23, 4669.

13. Wilkins, L. C.; Günter, B. A. R.; Walther, M.; Lawson, J. R.; Wirth, T.; Melen, R. L.; Angew. Chem., Int. Ed. 2016, 55, 11292. 
14. Parker, W. R.; Brodbelt, J. S.; J. Am. Soc. Mass Spectrom. 2016, 27, 1344.

15. Radhakrishna, P. M.; Sharadamma, K. C.; Vagdevi, H. M.; Abhilekha, P. M.; Rubeena, M. S.; Nischal, K.; Int. J. Chem. 2010, 2, 149.

16. Refat, M. S.; Abdel-Hafez, S. H.; Russ. J. Gen. Chem. 2016 , 86, 1151.

17. Deutch, C. E.; Spahija, I.; Wagner, C. E.; J. Appl. Microbiol. 2014, 117, 1487.

18. Abdel-Hafez, S. H.; Phosphorus, Sulfur Silicon Relat. Elem. 2010, 185, 37.

19. Kumar, S.; Sharma, N.; Maurya, I. K.; Bhasin, A. K. K.; Wangoo, N.; Brandão, P.; Félix, V.; Bhasin, K. K.; Sharma, R. K.; Eur. J. Med. Chem. 2016, 123, 916.

20. Kumar, S.; Sharma, N.; Maurya, I. K.; Verma, A.; Kumar, S.; Bhasin, K. K.; Sharma, R. K.; New J. Chem. 2017, 41, 2919.

21. Rosseti, I. B.; Wagner, C.; Fachinetto, R.; Taube Junior, P.; Costa, M. S.; Mycoses 2010, 54, 506.

22. Chagas, P. M.; Rosa, S. G.; Sari, M. H. M.; Oliveira, C. E. S.; Canto, R. F. S.; Luz, S. C. A.; Braga, A. L.; Nogueira, C. W.; Pharmacol., Biochem. Behav. 2014, 118, 87.

23. Baquedano, Y.; Alcolea, V.; Toro, M. A.; Gutiérrez, K. J.; Nguewa, P.; Font, M.; Moreno, E.; Espuela, S.; Jiménez-Ruiz, A.; Palop, J. A.; Plano, D.; Sanmartin, C.; Antimicrob. Agents Chemother. 2016, 60, 3802.

24. Fernández-Rubio, C.; Campbell, D.; Vacas, A.; Ibañez, E.; Moreno, E.; Espuelas, S.; Calvo, A.; Palop, J. A.; Plano, D.; Sanmartin, C.; Nguewa, P. A.; Antimicrob. Agents Chemother. 2015, 59, 5705.

25. Martín-Montes, Á.; Plano, D.; Martín-Escolano, R.; Alcolea, V.; Díaz, M.; Pérez-Silanes, S.; Espuelas, S.; Moreno, E.; Marín, C.; Gutiérrez-Sánchez, R.; Sanmartin, C.; Sánchez-Moreno, M.; Antimicrob. Agents Chemother. 2017, 61, 2546.

26. Sahu, P. K.; Umme, T.; Yu, J.; Nayak, A.; Kim, G.; Noh, M.; Jae-Young, L.; Kim, D. D.; Jeong, L. S.; J. Med. Chem. 2015, $58,8734$.

27. Pietka-Ottlik, M.; Potaczek, P.; Piasecki, E.; Mlochowski, J.; Molecules 2010, 15, 8214.

28. Athayde-Filho, P. F.; Souza, A. G.; Morais, S. A.; Botelho, J. R.; Barbosa-Filho, J. M.; Miller, J.; Lira, B. F.; Arkivoc 2004, 6, 22.

29. Ma, L.; Li, S.; Zheng, H.; Chen, J.; Lin, L.; Ye, X.; Chen, Z.; Xu, Q.; Chen, T.; Yang, J.; Qiu, N.; Wang, G.; Peng, A.; Ding, Y.; Wei, Y.; Chen, L.; Eur. J. Med. Chem. 2011, 46, 2003.

30. Veber, D. F.; Johnson, S. R.; Cheng, H. U.; Smith, B. R.; Ward, K. W.; Kopple, K. D.; J. Med. Chem. 2002, 45, 2615.

31. Lipinski, C. A.; Lombardo, F.; Dominy, B. W.; Feeney, P. J.; Adv. Drug Delivery Rev. 2001, 46, 3.
32. Lipinski, C. A.; Lombardo, F.; Dominy, B. W.; Feeney, P. J.; Adv. Drug Delivery Rev. 1997, 23, 3.

33. http://www.organic-chemistry.org/prog/peo/, accessed on February 01, 2018.

34. http://www.molinspiration.com/, accessed on February 01, 2018.

35. http://www.swissadme.ch/, accessed on February 01, 2018.

36. Zhao, M. Y.; Abraham, M. H.; Le, J.; Hersey, A.; Luscombe, C. N.; Beck, G.; Sherborne, B.; Pharm. Res. 2002, 19, 1446.

37. Gibbons, S.; Planta Med. 2008, 74, 594.

38. Radhakrishna, P. M.; Sharadamma, K. C.; Abhilekha, P. M.; Rubeena Mubeen, S.; Nischal, K.; Int. J. Chem. 2010, 2, 149.

39. Piętka-Ottlik, M.; Wójtowicz-Mıochowska, H.; KoŁodziejczyk, K.; Piasecki, E.; MŁochowski, J.; Chem. Pharm. Bull. 2008, 56, 1423.

40. Drakulić, B. J.; Juranić, I. O.; Erić, S.; Zloh, M.; Int. J. Pharm. 2008, 363, 40.

41. Zloh, M.; Kaatz, G. W.; Gibbons, S.; Bioorg Med. Chem. Lett. 2004, 14, 881 .

42. Korolkovas, A.; Burckhalter, J. H.; Química Farmacêutica, $2^{a}$ ed.; Guanabara Koogan: Rio de Janeiro, 1988.

43. Barreiro, E. J.; Fraga, C. A. M.; Química Medicinal: as Bases Moleculares da Ação dos Fármacos, $3^{\mathrm{a}}$ ed.; Artmed: Porto Alegre, 2014.

44. Holetz, F. B.; Howes, M. J.; Lee, C. C.; Steventon, G.; Mem. Inst. Oswaldo Cruz 2002, 97, 1027.

45. Kaatz, G. W.; Seo, S. M.; Ruble, C. A.; Antimicrob. Agents Chemother. 1993, 37, 1086.

46. Ross, J. I.; Farrell, A. M.; Eady, E. A.; Cove, J. H.; Cunliffe, W. J.; J Antimicrob. Chemother. 1989, 24, 851.

47. Gibbons, S.; Udo, E. E.; Phytother Res. 2000, 14, 139.

48. Clinical and Laboratory Standards Institute (CLSI); Document M100-S17, M7-A6: Performance Standards for Antimicrobial Susceptibility Testing; Approved Standard, $6^{\text {th }}$ ed.; CLSI: Wayne, PA, 2003.

49. National Committee for Clinical and Laboratory Standards (NCCLS); Performance Standards for Antimicrobial Disk Susceptibility Tests, $7^{\text {th }}$ ed.; NCCLS: Villanova, 2000.

50. Hadacek, F.; Greger, H.; Phytochem. Anal. 2000, 11, 137.

51. Cleeland, R.; Squires, E. In Evaluation of New Antimicrobials in vitro and in Experimental Animal Infections; Lorian, V., ed.; Antibiotics in Laboratory Medicine, Lippincott Williams \& Wilkins: Baltimore, 1991, p. 739.

Submitted: May 21, 2018

Published online: August 6, 2018 